\title{
A broader approach to recreational water quality assessment: Buenos Aires City case study
}

\author{
Mónica López Sardi ${ }^{1}$ (1) $\cdot$ Victoria Larroudé ${ }^{1}$
}

Received: 17 May 2018 / Accepted: 18 November 2019 / Published online: 29 January 2020

(c) The Author(s) 2020

\begin{abstract}
In the last decade, the world population has become more urban than rural, but the human contact with nature is still a necessity for a proper physical and mental development. The urban green areas are a significant part of the urban heritage, providing fundamental ecosystem services. They give us the possibility of having social and cultural interaction surrounded by nature. Water is usually part of the landscape of these areas. The quality of the recreational water in urban green areas impacts on multiple factors like soil, vegetation, aquatic and terrestrial life and public health. A complete evaluation of this quality requires applying different methodologies simultaneously. Samples were collected at eight sites of Buenos Aires City in order to assess the quality of its recreational water. Results were compared with water quality standards in established legislation and were ranked by the National Sanitation Foundation Water Quality Index (NSF-WQI). Euphotic zone transparency was used as a parameter of the impact on aquatic life, measuring the Secchi depth. A test for fecal coliform bacteria was used as a risk indicator for human health. In accordance with the NSF-WQI ranking, the eight sampling sites have medium or bad water quality. Fifty percent of the sites exceeded the allowed count of coliform bacteria. According to established legislation, five of the studied sites were found to be unsuitable for primary, secondary or passive aquatic activities. Of the remaining sites, two were suitable for passive activities and only one qualified to be suitable for all kinds of aquatic activities. Secchi depth measures reveal a bad water quality for aquatic life at four of the analyzed sites.
\end{abstract}

Keywords Green urban areas $\cdot$ Recreational water $\cdot$ Water quality assessment $\cdot$ Water quality index

\section{Introduction}

More than $50 \%$ of the world population is currently living in urban areas. Due to the stressful city lifestyle, the possibilities of entertaining and rest in a natural environment are the most valued ecosystem services of the urban green areas, required for a life of good quality and important for public health (Bolund and Hunhammar 1999; Niemela et al. 2010). Many social, cultural and sportive activities in the city are performed thanks to the existence of this green infrastructure (McPhearson et al. 2014). However, as a result of overpopulation, the green spaces in the large cities are exposed to many negative impacts that affect the resilience of the urban environment and deteriorate its quality.

Mónica López Sardi

elopez13@palermo.edu; mlopezsardi@gmail.com

1 Faculty of Engineering, Palermo University, Mario Bravo 1050, C.P. C1175ABT CABA, Argentina
Water is usually part of the landscape of green urban areas. Aquatic ecosystems (rivers, lakes, groundwater, coastal waters and seas) support the delivery of crucial ecosystem services (Grizzetti et al. 2016). The analysis of recreational water quality is usually focused on the detection of bacteria. According to Wade et al. (2003), the association between this quality and human health outcomes has been studied for almost 70 years. Contact with water also exposes human health to diverse physical and chemical hazards (WHO 2003). The analysis of recreational water quality must take into consideration the health of bathers without leaving aside the rest of potential impacts of recreational water quality over the environment. Water quality has impacts on the entire local ecosystem: soil, vegetation, fish, birds, insects and other animals. It is fundamental for many of the biogeochemical processes of the ecosystem and determinant for the aesthetic landscape value of the area (González Castelain 2013).

Water quality is composed of multiple related variables. A change in one of them can affect the others. In some 
cases, these changes have a negative impact over several of the ecosystem services associated with water (Keeler et al. 2012). Monitoring this quality is important to obtain scientific information that functions as an indicator of the urban environment state.

This research is focused on the study of the quality of the recreational water at the main green urban areas of Buenos Aires City, Argentina. In order to apply a broader vision than public health to determine the quality of recreational water, several analytical methodologies were simultaneously used.

\section{Methodology}

The sampling period was from March 2015 to March 2017. Samples were collected on a seasonal basis, four times a year for each site. The parameters analyzed were $\mathrm{pH}$, temperature, dissolved oxygen, 5-day biological oxygen demand, dissolved solids, nitrates, total phosphates, turbidity, transparency, fecal coliforms, arsenic and chromium VI. Results were compared with water quality standards established in national legislation and were ranked by the National Sanitation Foundation Water Quality Index (NSF-WQI). The transparency of the water was measured by a Secchi disk and used as an indicator of the impact on aquatic life.

Sample collection, stabilization, transportation and storage were made according to the Standard Methods for the Examination of Water and Wastewater (APHA 2012).

These measurements were made in situ with a portable meter: pH (S.M. 4500 B), electrical conductivity (Con) (S.M. 2510 B), and dissolved oxygen (DO) (S.M. $4500 \mathrm{O}$ B). Transparency ( $\mathrm{Tr}$ ) of the water was semiquantitatively estimated with a Secchi disk (ISO 7027), and water temperature with an infrared thermometer (NIST Traceable, ISO 17025). Triplicate samples were taken into sterilized borosilicate glass bottles (S.M. 9060) of $500 \mathrm{~mL}$ each and were transferred to the laboratory for further analysis. The samples were transported at $4{ }^{\circ} \mathrm{C}$ inside an isolated container using ice packs and gel packs. At the laboratory nitrates $\left(\mathrm{NO}_{3}{ }^{-}\right)$were determined by reduction of cadmium (S.M. $\left.4500 \mathrm{NO}_{3}{ }^{-} \mathrm{E}\right)$, phosphates $\left(\mathrm{PO}_{4}{ }^{3-}\right)$ by ascorbic acid method (S.M. $\left.4500 \mathrm{PO}_{4}{ }^{3-} \mathrm{E}\right)$, chromium VI $\left(\mathrm{Cr}^{6+}\right)$ by diphenylcarbohydrazide method (ASTM D 1687 Test Method A), arsenic (As) by semiquantitative method, Gutzeit modified (Luong et al. 2007), 5-day biological oxygen demand (BOD5) by dilution method (S. M. 5210 B), turbidity (Tur) by formazin method (S.M. 2130 B), dissolved solids (DS) estimated by conductivity measurements (Carlson 2005), and fecal coliforms (FC) by multiple tube fermentation technique (S.M. $9221 \mathrm{E}$ ). The temperature change of the water $(\Delta T)$ was calculated with respect to the average value of the surface waters temperature in the Metropolitan Area of Buenos Aires (AMBA) region. According to the Environmental Atlas of Buenos Aires (2010), the annual mean value is $20^{\circ} \mathrm{C}$. The water quality was rated by NSF-WQI calculation, was compared with established regulations based on international water quality standards and with Secchi depth recommendations. Table 1 summarizes the parameters analyzed and the used methods.

The NSF-WQI was developed in 1970 with the objective of providing a tool for evaluating water quality.

This index was selected because is one of the most frequently used for water quality assessment across the world (Lumb et al. 2011; Poonam et al. 2013) and it has great credibility since more than a hundred experts contributed to its development (Sutadian et al. 2016). The index allows studying the evolution of water quality for a specific site in a timeline, or for different sites of the same body of water at a given time in a reproducible way (Phadatare and Gawande 2016). It also allows a standardized comparison between different bodies of water. (Brown et al. 1970; Poonam et al. 2013).

Table 1 Parameters analyzed

\begin{tabular}{ll}
\hline Water quality parameter & Method \\
\hline $\mathrm{pH}$ & Portable meter, Standard Methods 4500 B \\
Electrical conductivity & Portable meter, Standard Methods 2510 B \\
Dissolved oxygen & Portable meter, Standard Methods 4500 O B \\
Transparency. Secchi depth & Secchi disk, ISO 7027 \\
Temperature & Infrared thermometer NIST Traceable, ISO 17025 \\
Nitrates & Reduction of cadmium, Standard Method $4500 \mathrm{NO}_{3}{ }^{-} \mathrm{E}$ \\
Phosphates & Ascorbic acid method, Standar Method 4500 $\mathrm{PO}_{4}{ }^{3-} \mathrm{E}$ \\
Chromium VI & Diphenylcarbohydrazide method, ASTM D 1687 Test Method A \\
Arsenic & Semiquantitative method, Gutzeit modified \\
5-day biological oxygen demand & Dilution method, Standard Method 5210 B \\
Turbidity & Formazin method, Standard Method 2130 B \\
Dissolved solids & Estimated by conductivity measurements \\
Fecal coliforms & Multiple tube fermentation technique, standard method 9221 E \\
\hline
\end{tabular}


Table 2 NSF-WQI (weight of the parameters)

\begin{tabular}{llllllllll}
\hline Factors & $\mathrm{DO}$ & $\mathrm{FC}$ & $\mathrm{pH}$ & $\mathrm{BOD}$ & $\Delta \mathrm{T}$ & $\mathrm{PO}_{4}{ }^{3-}$ & $\mathrm{NO}_{3}{ }^{-}$ & $\mathrm{Tur}$ & $\mathrm{DS}$ \\
\hline$W_{i}$ & 0.17 & 0.16 & 0.11 & 0.11 & 0.10 & 0.10 & 0.10 & 0.08 & 0.07 \\
\hline
\end{tabular}

The NSF-WQI is based on nine parameters selected by Delphi method. A subindex $Q_{i}$ is obtained for each parameter introducing the experimental value into the respective rating curve (Tyagi et al. 2013). Each parameter has been assigned a weight, as seen in Table 2 . The index is calculated as a weighted average, in accordance with the equation:

$\mathrm{WQI}=\sum_{i=1}^{n} W_{\mathrm{i}} * Q_{\mathrm{i}}$

Its score ranges from 0 to 100 , with 100 being the maximum score. According to the score, the NSF-WQI determines the status of the water body into five categories, namely excellent (91 to 100), good (71 to 90), medium (51 to 70), bad (26 to 50) and very bad (0 to 25) (Alexakis et al. 2016).

The obtained data were also compared with the parametric standard values proposed in the regulation issued by the Water Resources Secretariat of the Ministry of Interior (SSRH). This regulation defines the values associated with each category of use of the water, according to Tables 3 and 4 (Ministerio del Interior 2003).

In relation to public health, the fecal coliforms are accepted as fecal indicator bacteria, because they are more easily measured than other pathogens and more abundant in fecal material. This increases the likelihood of detection (Griffith et al. 2016).

Arsenic and hexavalent chromium are other important pollutants to consider when studying the water quality in relation to human health. The analysis of arsenic levels in Argentina is important because its frequent presence is responsible for chronic endemic regional hydroarsenicism (HACRE). In many regions of the country, including certain areas of Buenos Aires, the concentration of arsenic exceeds the level of $10 \mu \mathrm{g} / \mathrm{L}$ admitted by the World Health Organization (Litter 2010). The high degree of industrialization along the coast of the Río de la Plata generates a chromium hexavalent input (Licursi and Gomez 2013). According to Rocchetta et al. (2007), this pollutant is also present in the Riachuelo waters and the main discharge comes from tanning industry. Certain chromium hexavalent compounds are carcinogenic in humans. It can cause a wide range of other health effects such as allergic reactions, ulcers, liver damage, convulsions or even death. (Pellerin and Booker 2000).

Photosynthesis is possible only within a thin layer of the superficial waters in which at least $1 \%$ of the photosynthetically active radiation can penetrate. This zone is referred as euphotic depth. A simple way to assess the penetration of
Table 3 Uses of the water

\begin{tabular}{ll}
\hline Category & Use: water suitable for... \\
\hline I & Human consumption after conventional treatment \\
II & Recreational activity with direct contact (primary) \\
III & Recreational activity without direct contact (secondary) \\
IV & Passive recreational activities (aesthetic enjoyment) \\
V & Preservation of aquatic life with prolonged exposure \\
VI & Preservation of aquatic life without prolonged exposure \\
\hline
\end{tabular}

light into water is by using a Secchi disk (Padial and Thomaz 2008; Luhtala and Tolvanen 2013). Water absorbs or scatters light due to different factors like the color of the water, the presence of phytoplankton and presence of erosional materials suspended (Lee et al. 1995). The optimum Secchi depth for fish at lakes and lagoons varies in relation to the species of fish and the causes of the turbidity. According to Bhatnagar and Devi (2013), a range from 30 to $80 \mathrm{~cm}$ is good for fish health. Low transparency of the water causes fish stress. The Food and Agriculture Organization of the United Nations (FAO 2005) recommends a range from 40 to $60 \mathrm{~cm}$. A value less than $40 \mathrm{~cm}$ indicates the presence of an amount of plankton that endangers the survival of the fish during the night when there is no production of oxygen due to photosynthesis but respiration of plankton increases consumption. A transparency greater than $60 \mathrm{~cm}$ indicates low amounts of plankton and the fish may not have enough natural food.

\section{The city and the sampling sites}

The Autonomous City of Buenos Aires, known by the acronym CABA, is the capital city of Argentina. It has an area of $203.3 \mathrm{~km}^{2}$ (78.5 square miles) and according to the last national census, it has 2.89 million inhabitants. Buenos Aires is surrounded by an urban cluster known as Great Buenos Aires (GBA). This urban conglomerate is one of the largest in the southern hemisphere. The urban zone formed by GBA and CABA is called the Metropolitan Area of Buenos Aires (AMBA) and has an area of $2681 \mathrm{~km}^{2}$ (1035 square miles). According to the census of 2010 , the population estimate is 14.28 million inhabitants and the population density is 5.3 thousand people per $\mathrm{km}^{2}$ (13.8 thousand people per square mile). Buenos Aires AMBA is at the 21st place among the 1000 most populated cities in the world (Demographia 2017). It is estimated that $12 \%$ of the GBA inhabitants enter

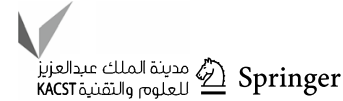


Table 4 Standard values of the analyzed parameters associated with each category of use
Fig. 1 Map of Buenos Aires City and the sampling sites (Mapoteca Educar)

\begin{tabular}{|c|c|c|c|c|c|c|}
\hline & I & II & III & IV & $\mathrm{V}$ & VI \\
\hline DO (mg/L) & $>4$ & $>5$ & $>5$ & $>2$ & $>5$ & $>3$ \\
\hline BOD5 (mg/L) & $<5$ & $<3$ & $<10$ & $<15$ & $<3$ & $<10$ \\
\hline $\mathrm{NO}_{3}^{-}(\mathrm{mg} / \mathrm{L})$ & $<10$ & $<10$ & $<10$ & NR & NR & NR \\
\hline $\mathrm{PO}_{4}{ }^{3-}(\mathrm{mg} / \mathrm{L})$ & NR & $<1$ & $<1$ & $<5$ & $<10$ & $<100$ \\
\hline $\mathrm{Cr}^{6}(\mu \mathrm{g} / \mathrm{L})$ & $<50$ & $<50$ & NR & NR & $<2$ & $<20$ \\
\hline As $(\mu \mathrm{g} / \mathrm{L})$ & $<50$ & $<50$ & NR & NR & $<150$ & $<340$ \\
\hline $\mathrm{pH}$ & $6-9$ & $6-9$ & $6-9$ & $6-9$ & $6-9$ & $4-10.5$ \\
\hline Temp $\left({ }^{\circ} \mathrm{C}\right)$ & NR & $15-35$ & $15-35$ & $<35$ & $\Delta T<3$ & $\Delta T<3$ \\
\hline FC (MPN/100 mL) & $<2000$ & $<200$ & $<20,000$ & NR & NR & NR \\
\hline
\end{tabular}

NR: with no restriction

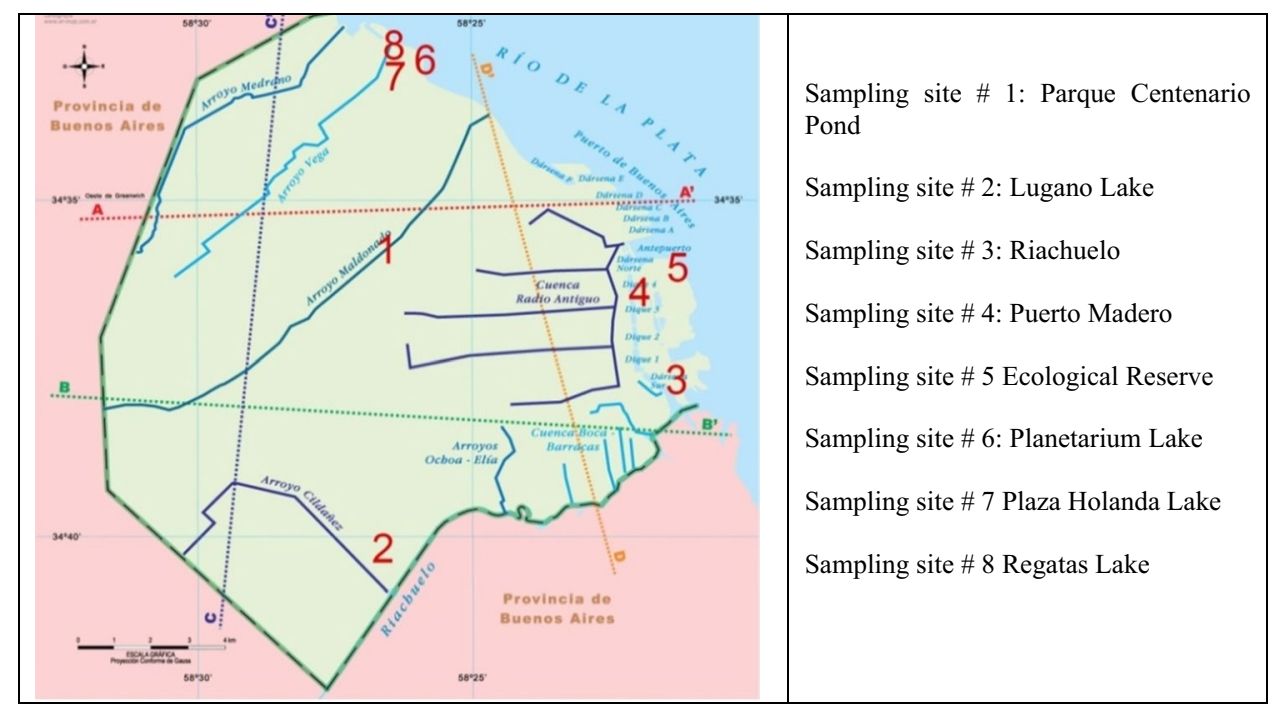

into CABA daily for work, study or for other reasons (Diario Clarín 2013). The city has 1055 green spaces that cover an area of 1924.5 ha (7.43 square miles). The relationship between this area and the population indicates that it corresponds to $6.3 \mathrm{~m}^{2}$ of green space per inhabitant (9765 square inches per capita) (Buenos Aires Ciudad 2017a).

Water is an important presence in the green spaces of Buenos Aires City. The east city limit is the Río de la Plata coast, surrounded by "La Costanera," an area of walks along the river. The south city limit is the Riachuelo (formerly Matanza River). Next to it, "Caminito," a picturesque tango corner of the city and a favorite place for tourists. The city also has another 19 important green urban areas of which 14 have ponds and lakes, where citizens and tourists run, walk, row and relax.

To assess the quality of the recreational water in Buenos Aires City, samples were collected at eight sites on the main green areas of the city. The sampling sites are marked over the map as shown in Fig. 1.

The description of the sampling sites and the activities performed in every location are shown in Table 5.

\section{Results and discussion}

Table 6 summarizes the results obtained for the different parameters analyzed. Due to the minimum seasonal variation observed, the values presented in this study correspond to the average result for each sampling site.

Table 7 shows the subindex $\left(Q_{i}\right)$ for the nine parameters (factors) required by the NSF-WQI, obtained by transferring each parameter value to the corresponding rating curve.

Table 8 shows the results for the NSF-WQI at each sampling site.

In accordance to the NSF-WQI ranking, the eight sampling sites have bad or medium water quality.

In the sites covered by this study, people engage in outdoor activities such as sporting or recreational rowing, biking, skating, running and walking around the water. Comparing the obtained results with the regulations of the SSRH, as seen in Table 9, sampling site \#1 allows primary, secondary and passive recreational uses of the water, and sampling sites \#2 and \#6 only admits passive recreational activities. The 


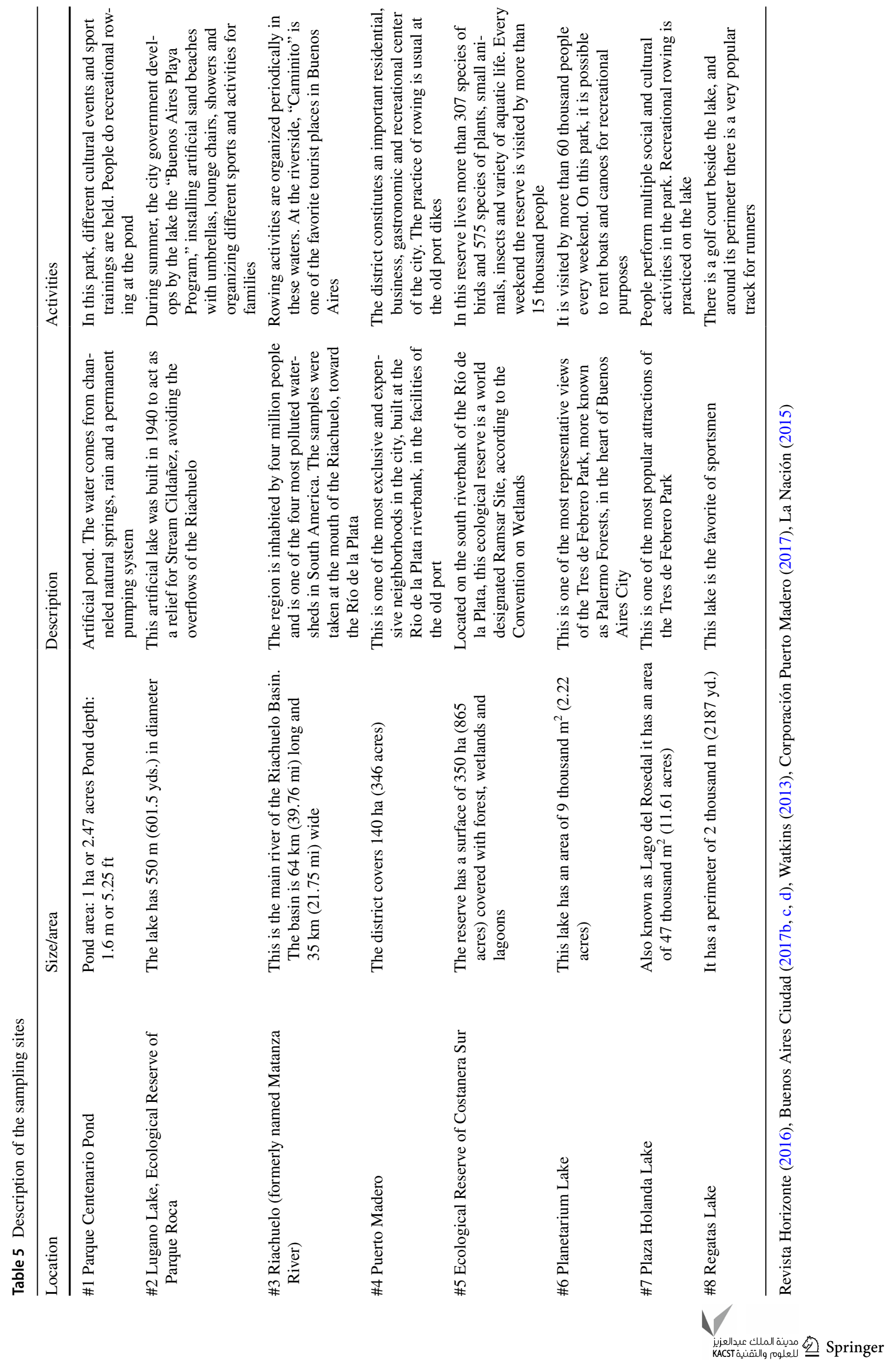


Table 6 Parameters values for each sampling site

\begin{tabular}{lllllcccc}
\hline Sampling site & $\# 1$ & $\# 2$ & $\# 3$ & $\# 4$ & $\# 5$ & $\# 6$ & $\# 7$ & $\# 8$ \\
\hline $\mathrm{DO}(\mathrm{mg} / \mathrm{L})$ & 11.6 & 5.25 & 1.5 & 6.8 & 2.8 & 4.3 & 5.6 & 4.3 \\
$\mathrm{BOD}_{5}(\mathrm{mg} / \mathrm{L})$ & $<5$ & $<5$ & 48.7 & $<5$ & 41.4 & 6.8 & 9.5 & 1.5 \\
$\mathrm{NO}_{3}{ }^{-}(\mathrm{mg} / \mathrm{L})$ & $<10$ & 1 & $<10$ & $<5$ & $<10$ & $<10$ & $<10$ & $<10$ \\
$\mathrm{PO}_{4}{ }^{3-}(\mathrm{mg} / \mathrm{L})$ & $<1$ & 5 & $<1$ & $<1$ & $<1$ & $<1$ & 1.5 & $<1$ \\
$\mathrm{Cr}^{6+}(\mu \mathrm{g} / \mathrm{L})$ & 28 & 0 & 29 & 14 & 0 & 51 & 57 & 110 \\
$\mathrm{As}(\mu \mathrm{g} / \mathrm{L})$ & 40 & 20 & 100 & 0 & 20 & 0 & 0 & 0 \\
$\mathrm{pH}$ & 6 & 6 & 7.5 & 5 & 5 & 9.6 & 10 & 6.7 \\
$\Delta T\left({ }^{\circ} \mathrm{C}\right)$ & 1.3 & 2.4 & 1.7 & 1.7 & 2.5 & 2.8 & 3.7 & 4 \\
$\mathrm{FC}(\mathrm{MPN} / 100 \mathrm{~mL})$ & $<3$ & 460 & 110,000 & 9300 & 43 & 2 & 1100 & 4 \\
$\mathrm{Tur}(\mathrm{NTU})$ & 20 & 36 & 34 & 18 & 40 & 6 & 18 & 5 \\
$\mathrm{DS}(\mathrm{mg} / \mathrm{L})$ & 171 & 665 & 463 & 408 & 313 & 203 & 936 & 156 \\
$\mathrm{Con}(\mu \mathrm{S} / \mathrm{cm})$ & 342 & 1331 & 927 & 817 & 626 & 405 & 1873 & 313 \\
$\operatorname{Tr}(\mathrm{cm})$ & 40 & 24 & 26.5 & 46.5 & 22 & 18.5 & 47.5 & 58.5 \\
\hline
\end{tabular}

\begin{tabular}{lllrlllll}
\hline Factors & $\# 1$ & $\# 2$ & $\# 3$ & $\# 4$ & $\# 5$ & $\# 6$ & $\# 7$ & $\# 8$ \\
\hline FC & 86 & 29 & 2 & 10 & 54 & 91 & 22 & 82 \\
DS & 76 & 20 & 38 & 45 & 58 & 72 & 20 & 78 \\
DO & 92 & 56 & 11 & 87 & 19 & 41 & 60 & 41 \\
pH & 55 & 55 & 93 & 27 & 27 & 29 & 20 & 79 \\
Tur & 61 & 48 & 50 & 63 & 45 & 84 & 63 & 86 \\
$\mathrm{BOD}^{-}$ & 56 & 56 & 5 & 56 & 5 & 47 & 36 & 90 \\
$\mathrm{NO}_{3}{ }^{3-}$ & 51 & 96 & 51 & 65 & 51 & 51 & 51 & 51 \\
$\mathrm{PO}_{4}{ }^{-}$ & 40 & 13 & 40 & 40 & 40 & 40 & 31 & 40 \\
$\Delta T$ & 88 & 83 & 86 & 86 & 83 & 82 & 78 & 77 \\
\hline
\end{tabular}

\begin{tabular}{lllllllll}
\hline Sampling site & $\# 1$ & $\# 2$ & $\# 3$ & $\# 4$ & $\# 5$ & $\# 6$ & $\# 7$ & $\# 8$ \\
\hline WQI & 70 & 51 & 37 & 53 & 42 & 59 & 42 & 68
\end{tabular}

Table 8 NSF-WQI results for the sampling sites

Table 7 Value of the subindex $Q_{i}$ for each factor

Table 9 Possible water uses at the sampling sites

\begin{tabular}{lcccccc}
\hline Sampling site & Cat. I & Cat. II & Cat. III & Cat. IV & Cat. V & Cat. VI \\
\hline$\# 1$ & $\checkmark$ & $\checkmark$ & $\checkmark$ & $\checkmark$ & $\times$ & $\times$ \\
$\# 2$ & $\checkmark$ & $\times$ & $\times$ & $\checkmark$ & $\times$ & $\checkmark$ \\
$\# 3$ & $\times$ & $\times$ & $\times$ & $\times$ & $\times$ & $\times$ \\
$\# 4$ & $\times$ & $\times$ & $\times$ & $\times$ & $\times$ & $\checkmark$ \\
$\# 5$ & $\times$ & $\times$ & $\times$ & $\times$ & $\times$ & $\times$ \\
$\# 6$ & $\times$ & $\times$ & $\times$ & $\checkmark$ & $\times$ & $\times$ \\
$\# 7$ & $\times$ & $\times$ & $\times$ & $\times$ & $\times$ & $\checkmark$ \\
\hline & $\times$ & $\times$ & $\times$ & $\times$ & $\times$ & $\times$ \\
\hline
\end{tabular}

water quality of the other five sampling sites does not meet the requirements of the SSRH regulations for the performance of recreational activities.

Secchi disk depth is less than $30 \mathrm{~cm}$ in sampling sites \#2, \#3, \#5 and \#6 (see Table 3). The low transparency on these sites may cause stress to some fish species.
The explanation of the presence of $\mathrm{Cr}^{6+}$ and the elevated fecal coliform count in some of the lakes that do not receive directly sewage or industrial effluents can be found by the analysis of the hydrological setting of the city. Under Buenos Aires run several piped streams. The most important of them are Medrano stream, Vega stream, Maldonado stream and 
Table 10 Summary of results

\begin{tabular}{|c|c|c|c|c|c|}
\hline Sampling site & NSF-WQI quality & Use as recreational waters & $\begin{array}{l}\text { Presence of } \\
\mathrm{Cr}^{6+}\end{array}$ & $\begin{array}{l}\text { Presence of } \\
\text { As }\end{array}$ & Secchi depth \\
\hline \#1 & Medium & Primary, secondary, passive activities & + & + & Suitable for fish \\
\hline \#2 & Medium & Only passive activities & - & + & Fish stress \\
\hline \#3 & $\mathrm{Bad}$ & None & + & + & Fish stress \\
\hline \#4 & Medium & None & + & - & Suitable for fish \\
\hline$\# 5$ & Bad & None & - & + & Fish stress \\
\hline \#6 & Medium & Only passive activities & + & - & Fish stress \\
\hline \#7 & $\mathrm{Bad}$ & None & + & - & Suitable for fish \\
\hline \#8 & Medium & None & + & - & Suitable for fish \\
\hline
\end{tabular}

Radio Antiguo Basin (see Fig. 1). These streams were channeled to prevent city floods. All of them are connected to the highly contaminated Río de la Plata. The waters of this river are polluted due to the dumping of effluents from different sources without a correct treatment. These wastewaters come from the two main cities of the country: Buenos Aires and La Plata (Colombo et al. 1989). The presence of strong winds from the south-southeast quadrant coinciding with the axis of the river is a common meteorological phenomenon known as Sudestada. This wind drags on the waters of the river, which produces the increase in the level of the waters on the coast of Buenos Aires. According to the National Meteorological Service (SMN 2000), it makes difficult the drainage of smaller channels and brings the Riachuelo waters up to the city. This indirect contact with the Río de la Plata, polluted by the Riachuelo waters, through the piped streams can explain the level of contamination with $\mathrm{Cr}^{6+}$ of the ornamental lakes on sampling sites \#1, \#6, \#7 and \#8.

Table 10 shows a summary of results for each sampling site. Sampling site \#1 has the best water quality status, according to the ranking of the NSF. The explanation of this result may be related to the origin of the water. This pond is connected to several natural springs but its level is also maintained thanks to a clean water pumping system. The stream Cildáñez connects the Riachuelo with sampling site \#2 (Lago Lugano) to prevent floods over the city. This connection with the fourth most polluted watershed in South America explains the poor water quality of the lake. Sampling site \#3 is at the Riachuelo riverside and has the poorest quality of all the sites analyzed. The pollution of this river is one of the biggest environmental issues of Buenos Aires. The lack of planning for land use, with no urban planning nor sanitation infrastructure, and the disorderly location of industries are some of the historical causes of the pollution of this basin. Its remediation represents a challenge that different governments have not yet been able to solve (Faggi et al. 2015). Sampling sites
\#4 and \#5 are on the Río de la Plata riverside. The results reflect the serious environmental status of this river. Sampling sites \#6, \#7 and \#8 are located in a park at one of the most beautiful, important and elegant neighborhoods of the city. These lakes are connected to the channeled stream Vega. This connection and the periodical occurrence of the Sudestada phenomenon explain the low quality of its waters and the presence of $\mathrm{Cr}^{6+}$, a clearly industrial pollutant.

\section{Conclusion}

The study of recreational water quality with a broad point of view than public health allows identifying potential risks over the different environmental components of the urban green areas. To prevent the deterioration of the ecosystem services provided by these areas, the city government must consider including the monitoring, improvement and maintenance of the quality of the recreational water of the city in its public policies. As an outcome of this study, recommendations for the implementation of protection tasks, as well as the promotion of a law stating the sanitary and environmental emergency of the studied areas were given to the city government.

Open Access This article is licensed under a Creative Commons Attribution 4.0 International License, which permits use, sharing, adaptation, distribution and reproduction in any medium or format, as long as you give appropriate credit to the original author(s) and the source, provide a link to the Creative Commons licence, and indicate if changes were made. The images or other third party material in this article are included in the article's Creative Commons licence, unless indicated otherwise in a credit line to the material. If material is not included in the article's Creative Commons licence and your intended use is not permitted by statutory regulation or exceeds the permitted use, you will need to obtain permission directly from the copyright holder. To view a copy of this licence, visit http://creativecommons.org/licenses/by/4.0/.

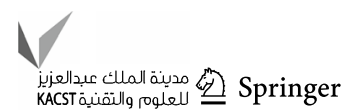




\section{References}

Alexakis D, Tsihrintzis VA, Tsakiris G, Gikas GD (2016) Suitability of water quality indices for application in lakes in the Mediterranean. Water Resour Manag 30(5):1621-1633

APHA (2012) Standard methods for the examination of water and wastewater. American Public Health Association, Washington, DC

ASTM (1992) Manual of Water and Environmental Technology. D 1687-92. Diphenylcarbohydrazide method

Atlas Ambiental de Buenos Aires (2010) Río. Aguas. Propiedades del agua. Temperatura. http://www.atlasdebuenosaires.gov.ar/aaba/ index.php?option $=$ com_content $\&$ task $=v i e w \& i d=318 \&$ Itemi $\mathrm{d}=184$. Accessed 30 Nov 2017

Bhatnagar A, Devi P (2013) Water quality guidelines for the management of pond fish culture. Int J Environ Sci 3(6):1980

Bolund P, Hunhammar S (1999) Ecosystem services in urban areas. Ecol Econ 29(2):293-301

Brown RM, McClelland NI, Deininger RA, Tozer RZ (1970) A water quality index-do we dare? Water Sewage Works 117:339-343

Buenos Aires Ciudad (2017a) Ciudad de Buenos Aires. http://www. buenosaires.gob.ar/laciudad/ciudad. Accessed 10 Nov 2017

Buenos Aires Ciudad (2017b) Vení a conocer el Parque Natural Lago Lugano. http://www.buenosaires.gob.ar/agenciaambiental/veniconocer-el-parque-natural-lago-lugano. Accessed 08 Nov 2017

Buenos Aires Ciudad (2017c) Reserva Ecológica. http://www.bueno saires.gob.ar/ciudadverde/espaciosverdes/reservaecologica. Accessed 16 Nov 2017

Buenos Aires Ciudad (2017d) Los lagos. http://www.buenosaire s.gob.ar/ciudadverde/espaciosverdes/parquetresdefebrero/loslagos. Accessed on 16 Nov 2017

Carlson G (2005) Total dissolved solids from conductivity. Technical Note In Situ Inc, 14

Colombo JC, Pelletier E, Brochu C, Khalil M, Catoggio JA (1989) Determination of hydrocarbon sources using n-alkane and polyaromatic hydrocarbon distribution indexes. Case study: Rio de la Plata estuary, Argentina. Environ Sci Technol 23(7):888-894

CPM (2017) Puerto Madero. Official Puerto Madero website. http:// www.puertomadero.com/\#/es/puertomadero. Accessed 16 Nov 2017

Demographia (2017) World Urban Areas. 13th Annual Edition: 2017: 04 http://www.demographia.com/db-worldua.pdf. Accessed 10 Nov 2017

Diario Clarín (2013) Casi la mitad de quienes trabajan en Capital llega desde el GBA. https://www.clarin.com/sociedad/mitad-trabajanCapital-llega-GBA_0_SJOz-EjwXe.html. Accessed 10 Nov 2017

Faggi A, Breuste J, Melignani E, Johnson BG (2015) Estado y percepción de los servicios ecosistémicos de las riberas del MatanzaRiachuelo. Eur Sci J ESJ 11(10):296-305

Food and Agricultural Organization of the United Nations (2005) Mejora de la calidad de agua en los estanques. http://www.fao. org/fishery/static/FAO_Training/FAO_Training/General/x6709s/ x6709s02.htm. Accessed 13 Mar 2018

González Castelain J (2013) Ecohidrología: el agua y los procesos ecosistémicos. https://www.unicen.edu.ar/content/ecohidrolo g\%C3\%AD-el-agua-y-los-procesos-ecosist\%C3\%A9micos. Accessed 10 Mar 2018

Griffith JF, Weisberg SB, Arnold BF, Cao Y, Schiff KC, Colford JM Jr (2016) Epidemiologic evaluation of multiple alternate microbial water quality monitoring indicators at three California beaches. Water Res 94:371-381

Grizzetti B, Lanzanova D, Liquete C, Reynaud A, Cardoso AC (2016) Assessing water ecosystem services for water resource management. Environ Sci Policy 61:194-203
ISO (1990) ISO 7027. Water quality. Determination of turbidity. International Standards Organization, Geneva

ISO (2005) ISO 17025 General requirements for the competence of testing and calibration laboratories. ISO, Geneva

ISO (2017) ISO/DIS 7027-2 (en). Water quality. Determination of turbidity. Semi-quantitative method for the assessment of transparency of waters. Chapter 5.1

Keeler BL, Polasky S, Brauman KA, Johnson KA, Finlay JC, O’Neill A et al (2012) Linking water quality and well-being for improved assessment and valuation of ecosystem services. Proc Natl Acad Sci 109(45): 18619-18624

La Nación (2015) Parques Porteños: cada semana van 130000 personas. https://www.lanacion.com.ar/1809450-parques-portenos-cada-finde-semana-van-130-mil-personas. Accessed 16 Nov 2017

Lee GF, Jones-Lee A, Rast W (1995) Secchi depth as a water quality parameter. Report of G. Fred Lee \& Associates. http://www.gfred lee.com/secchi.html. Accessed 22 Nov 2017

Licursi M, Gomez N (2013) Short-term toxicity of hexavalent-chromium to epipsammic diatoms of a microtidal estuary (Río de la Plata): responses from the individual cell to the community structure. Aquat Toxicol 134:82-91

Litter MI (2010) The problem of arsenic in Argentina. Rev SAEGRE 17:5-10

Luhtala H, Tolvanen H (2013) Optimizing the use of Secchi depth as a proxy for euphotic depth in coastal waters: an empirical study from the Baltic Sea. ISPRS Int J Geo Inf 2(4):1153-1168

Lumb A, Sharma TC, Bibeault JF (2011) A review of genesis and evolution of water quality index (WQI) and some future directions. Water Qual Expo Health 3(1):11-24

Luong JHT, Majid E, Male KB (2007) Analytical tools for monitoring arsenic in the environment. Open Anal Chem J 1(1):7-14

McPhearson T, Hamstead ZA, Kremer P (2014) Urban ecosystem services for resilience planning and management in New York City. Ambio 43(4):502-515. https://doi.org/10.1007/s 1328 0-014-0509-8

Ministerio de Educación. Presidencia de la Nación. (n.d.) Atlas interactivo. Ciudad de Buenos Aires, mapa físico. http://mapoteca.educ. ar/.files/index.html.1.5.html. Accessed on 08 Nov 2017

Ministerio del Interior, obras públicas y vivienda. Presidencia de la Nación. Subsecretaría de Recursos Hídricos (2003) Anexo: Criterios utilizados para la definición de los valores asociados a cada zona de uso. http://www.acumar.gov.ar/ACUsentencias/Causa Mendoza/2009abril/060409e/AnexoIIusos060409.pdf. Accessed 22 July 2017

Niemela J et al (2010) Using the ecosystem services approach for better planning and conservation of urban green spaces: a Finland case study. Biodivers Conserv 19:3225-3243. https://doi.org/10.1007/ s10531-010-9888-8

Padial AA, Thomaz SM (2008) Prediction of the light attenuation coefficient through the Secchi disk depth: empirical modeling in two large Neotropical ecosystems. Limnology 9(2):143-151

Pellerin C, Booker SM (2000) Reflections on hexavalent chromium: health hazards of an industrial heavyweight. Environ Health Perspect 108(9):A402

Phadatare S, Gawande S (2016) Review paper on development of water quality index. Int J Eng 5(05):765-767

Poonam T, Tanushree B, Sukalyan C (2013) Water quality indicesimportant tools for water quality assessment: a review. Int J Adv Chem 1(1):15-28

Revista Horizonte (2016) Caballito te quiero. Parques y Plazas. Parque Centenario. http://caballitotequiero.com.ar/portal/portfolio-item/ parque-centenario/. Accessed 08 Nov 2017

Rocchetta I, Leonardi PI, Amado Filho GM, del Carmen Ríos de Molina M, Conforti V (2007) Ultrastructure and X-ray microanalysis of Euglena gracilis (Euglenophyta) under chromium stress. Phycologia 46(3):300-306 
SMN (2000) Sudestada. http://www.smn.gov.ar/?mod=biblioteca \&id=71. Accessed 01 Dec 2017

Sutadian AD, Muttil N, Yilmaz AG, Perera BJC (2016) Development of river water quality indices-a review. Environ Monit Assess 188(1):58

Tyagi S, Sharma B, Singh P, Dobhal R (2013) Water quality assessment in terms of water quality index. Am J Water Resour 1(3):34-38

Wade TJ, Pai N, Eisenberg JN, Colford JM Jr (2003) Do US environmental protection agency water quality guidelines for recreational waters prevent gastrointestinal illness? A systematic review and meta-analysis. Environ Health Perspect 111(8):1102

Watkins K (2013) Las cuatro cuencas hidrográficas más contaminadas de Sudamérica. BN Américas. https://www.bnamericas.com/es/ reportajes/aguasyresiduos/las-cuatro-cuencas-hidrograficas-mascontaminadas-de-sudamerica. Accessed 16 Nov 2017

WHO (2003) Healthy recreational waters. http://www.who.int/featu res/2003/10/en/. Accessed 02 Dec 2017

Publisher's Note Springer Nature remains neutral with regard to jurisdictional claims in published maps and institutional affiliations. 